UDC 539.3

\title{
THERMOELASTICITY OF ELASTOMERIC CONSTRUCTIONS WITH INITIAL STRESSES
}

\author{
V.A. Bazhenov ${ }^{1}$, \\ Doctor of Technical Science \\ Yu.G. Kozub ${ }^{2}$, \\ Doctor of Technical Science \\ I.I. Solodei ${ }^{1}$, \\ Doctor of Technical Science \\ ${ }^{1}$ Kyiv National University of Construction and Architecture \\ 31, Povitroflotsky ave., Kyiv, Ukraine, 03680 \\ ${ }^{2}$ Luhansk Taras Shevchenko National University \\ 1 Gogol Square, the City of Starobilsk, Luhansk Region, Ukraine, 92703
}

DOI: $10.32347 / 2410-2547.2020 .104 .299-308$

\begin{abstract}
The article presents an algorithm for solving linked problems of thermoelasticity of elastomeric structural elements on the basis of a moment scheme of finite elements. To model the processes of thermoelastic deformation of structures with initial stresses the incremental theory of a deformed solid is used. At each step of deformation, the stiffness matrix is adjusted using an incremental geometric stiffness matrix. The use of triple approximation of displacements, deformations and volume change function allows to consider the weak compressibility of elastomers. The components of the stress tensor are calculated according to the Duhamel-Neumann law. To solve the problem of thermal conductivity, a thermal conductivity matrix considering the boundary conditions on the surface of a finite element is constructed. A sequential approximation algorithm is used to solve the thermoelasticity problem. At each stage of the solution, the characteristics of the thermal stress state are calculated. Based on the obtained components of stress and strain tensors, the intensity of internal heat sources is calculated as the dissipative energy averaged over the load cycle. To calculate the dissipative characteristics of the viscoelastic elastomer the parameters of the Rabotnov's relaxation nucleus are used. Solving the problem of thermal conductivity considering the function of internal heat sources allows you to specify the heating temperature of the body. At each cycle of the algorithm, the values of the physical and mechanical characteristics of the thermosensitive material are refined. This approach to solving thermoelastic problems is implemented in the computing complex "MIRELA+". Based on the considered approach, the solutions of a number of problems are obtained. The results obtained satisfactorily coincide with the solutions of other authors. Considering the effect of preload and the dependence of physical and mechanical properties of the material on temperature leads to significant adjustments to the calculated values.
\end{abstract}

Key words: finite element method, elastomer, thermoelasticity, dissipative warming, initial stresses.

Introduction. In solving related problems of thermoelasticity of elastomeric structural elements, various theories and approaches are used, which are based on the relations of the thermoelasticity obtained by many researchers [1-6] and others. One of the most important criteria for the study of viscoelastic bodies with a non-uniform temperature field is to take into account the temperature dependence of physical and thermophysical characteristics of the material: 
modulus of elasticity or shear modulus, coefficient of thermal expansion and coefficient of thermal conductivity

In the case of a slight increase in temperature, its effect on the mechanical behaviour of the viscoelastic body can be neglected and an unrelated problem of thermovisoelasticity can be considered. This approach is reflected in [7] and others.

When using a coupled linear model, the temperature and thermoelastic states are determined by the solution of the system, which consists of the equations of thermal conductivity, classical equations of motion, Hooke's law equations and classical compatibility equations [8-11], etc.

It is obvious that all thermomechanical processes depend on time and for their research there are problems called non-stationary (dynamic). However, we can identify a number of processes, thermomechanical state, during which, although it changes over time, but from a certain point in time, the system comes to a stationary (static) state, which does not depend on time. In addition, it should be noted that elastomers are a nonlinear viscoelastic material and their stress-strain state depends on the load history.

1. Problem statement and its solution. The formulation of the related problem for a quasi-stationary formulation can be represented as the equation Biot and the equation of thermal conductivity [11].

The formulation of the initial provisions for the description of the deformation process considering the initial stresses will begin with the representation of this process as a sequence of equilibrium states:

$$
\Omega^{(0)}, \Omega^{(1)}, \Omega^{(2)}, \ldots \Omega^{(n)}, \ldots . \Omega^{(L)},
$$

where $\Omega^{(0)}, \Omega^{(L)}$ - initial and final state of deformation respectively; $\Omega^{(n)}$ arbitrary intermediate state.

It is considered that for all intermediate states of stress, strain, displacement

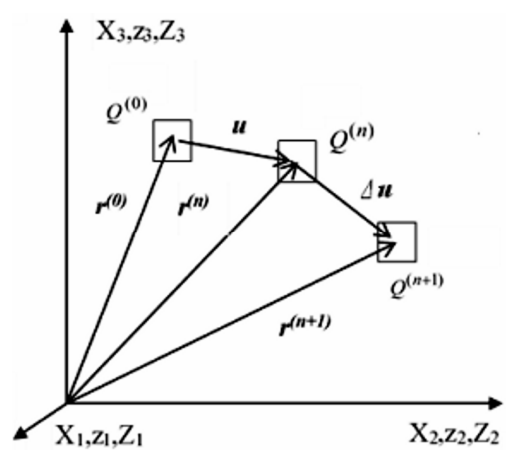

Fig. 1. States $\Omega^{(0)}, \Omega^{(n)}, \Omega^{(n+1)}$ known throughout the history of deformation to the state $\Omega^{(n)}$. Let the position of an arbitrary point of a body in states $\quad \Omega^{(0)}, \quad \Omega^{(n)}, \Omega^{(n+1)} \quad$ are determined by the radius vectors of these points $\mathbf{r}^{(0)}, \mathbf{r}^{(n)}, \mathbf{r}^{(n+1)}$. The body is referred to the basic Cartesian coordinate system and the coordinates of the points are respectively equal $X_{i}, z_{i}, Z_{i} \quad(i=1,2,3)$.

Let us denote the tensors of Green's deformations in states $\Omega^{(n)}$ and $\Omega^{(n+1)}$ through $\varepsilon_{i j}^{0}$ i $\varepsilon_{i j}^{0}+\varepsilon_{i j}$ respectively:

$$
\varepsilon_{i j}^{0}=\frac{1}{2}\left(\mathbf{r}_{, i}^{(n)} \mathbf{r}_{, j}^{(n)}-\mathbf{r}_{, i}^{(0)} \mathbf{r}_{, j}^{(0)}\right)=\frac{1}{2}\left(u_{i, j}+u_{j, i}+u_{k, i} u_{k, j}\right),
$$




$$
\begin{gathered}
\varepsilon_{i j}^{0}+\varepsilon_{i j}=\frac{1}{2}\left(\mathbf{r}_{, i}^{(n+1)} \mathbf{r}_{, j}^{(n+1)}-\mathbf{r}_{, i}^{(0)} \mathbf{r}_{, j}^{(0)}\right)= \\
=\frac{1}{2}\left(\left(u_{i}+\Delta u_{i}\right)_{, j}+\left(u_{j}+\Delta u_{j}\right)_{, i}+\left(u_{k}+\Delta u_{k}\right)_{, i}\left(u_{k}+\Delta u_{k}\right)_{, j}\right) .
\end{gathered}
$$

On the other hand, taking the initial state $\Omega^{(n)}$ and using the rectangular coordinates of the increase in deformation can be determined [12]:

$$
\varepsilon_{i j}^{*}=\frac{1}{2}\left(\frac{\partial \mathbf{r}^{(n+1)}}{\partial z_{i}} \frac{\partial \mathbf{r}^{(n+1)}}{\partial z_{j}}-\frac{\partial \mathbf{r}^{(n)}}{\partial z_{i}} \frac{\partial \mathbf{r}^{(n)}}{\partial z_{j}}\right)=\frac{1}{2}\left(\frac{\partial \Delta u_{i}}{\partial z_{j}}+\frac{\partial \Delta u_{j}}{\partial z_{i}}+\frac{\partial \Delta u_{k}}{\partial z_{i}} \frac{\partial \Delta u_{k}}{\partial z_{j}}\right) .
$$

The increments of deformations are connected by the relations:

$$
\varepsilon_{i j}^{*}=\frac{\partial X_{m}}{\partial z_{i}} \frac{\partial X_{n}}{\partial z_{j}} \varepsilon_{m n,} \quad \varepsilon_{i j}=\frac{\partial z_{m}}{\partial X_{i}} \frac{\partial z_{n}}{\partial X_{j}} \varepsilon_{m n}^{*} .
$$

The components of the deformation gain tensor can be represented as linear and nonlinear components:

$$
\varepsilon_{i j}^{*}=\varepsilon_{i j}^{*^{L}}+\varepsilon_{i j}^{*^{N}}=\frac{1}{2}\left(\frac{\partial \Delta u_{i}}{\partial z_{j}}+\frac{\partial \Delta u_{j}}{\partial z_{i}}\right)+\frac{1}{2} \frac{\partial \Delta u_{k}}{\partial z_{i}} \frac{\partial \Delta u_{k}}{\partial z_{j}} .
$$

Jacobian transformations: $D^{(n)}=\left|z_{i, j}\right|, D^{(n+1)}=\left|Z_{i, j}\right|$,

$$
z_{i, j}=\delta_{i j}+u_{i, j}, Z_{i, j}=\delta_{i j}+\left(u_{i}+\Delta u_{i}\right)_{, j} .
$$

To describe a stress state, we introduce the Euler stress tensor. At points $Q^{(n)}$, the components of the stress tensor have the value of $\sigma_{0}^{i j}$, acting on the faces $z_{i}$-const, $\left(z_{i}+d z_{i}\right)-$ const and $\sigma_{0}^{i j}+\sigma^{i j}$, which acting on the faces $Z_{i}-$ const, $\left(Z_{i}+d Z_{i}\right)$ - const an infinitesimal parallelepiped including a point $Q^{(n+1)}$.

At the point $Q^{(n+1)}$ the stress can be described by a modified Kirchhoff tensor [12].

$$
\begin{aligned}
\sigma_{0}^{i j}+\sigma^{i j^{*}} & =\frac{1}{D^{(n)}} \frac{\partial z_{i}}{\partial X_{k}} \frac{\partial z_{j}}{\partial X_{l}}\left(\sigma_{0}^{k l}+\sigma^{k l}\right), \\
\sigma^{i j^{*}} & =\frac{1}{D^{(n)}} \frac{\partial z_{i}}{\partial X_{k}} \frac{\partial z_{j}}{\partial X_{l}} \sigma^{k l} .
\end{aligned}
$$

Variational statement of the problem for an elastic body with initial stresses with given additional mass and surface forces in the form of the principle of virtual work in the state $\Omega^{(n+1)}$ looks like:

$$
\iiint_{V}\left[\left(\sigma_{0}^{i j}+\sigma^{i j^{*}}\right) \delta \varepsilon_{i j}^{*}+\left(q_{i}^{0}+q_{i}\right) \delta u_{i}\right] d V-\iint_{S}\left(p_{i}^{0}+p_{i}\right) \delta \Delta u_{i} d S^{(n)}=0,
$$

where $p_{i}, q_{i}-$ vectors of surface and volumetric additional forces at $n+1$ step.

If $\Omega^{(n)}$ - equilibrium state, then in the equation the terms of the variation of elastic energy and taking into account the initial stress: 


$$
\iiint_{V}\left[\sigma_{0}^{i j} \delta \varepsilon_{i j}^{*}-q_{i}^{0} \delta u_{i}\right] d V^{n}-\iint_{S} p_{i}^{0} \delta u_{i} d S^{n}=0
$$

The equilibrium equation takes the form:

$$
\iiint_{V}\left[\sigma^{i j^{*}} \delta \varepsilon_{i j}^{*}-\frac{1}{2} \sigma_{0}^{i j} \delta\left(\frac{\partial \Delta u_{k}}{\partial z_{i}} \frac{\partial \Delta u_{k}}{\partial z_{j}}\right)-q_{i} \delta \Delta u_{i}\right] d V^{(n)}-\iint_{S} p_{i} \delta \Delta u_{i} d S^{(n)}=0 .
$$

To study the stress-strain state of spatial structures made of elastomers, consider the isoparametric finite element in the form of a hexagonal parallelepiped with an edge length of 2 . The origin of the basic coordinate system $Z_{i}$ and an arbitrary local system $x_{i}$, the axis of which coincides with the direction of its edges, placed in the centre of the cube. Consider the construction of matrices of stiffness of a finite element with initial stresses based on the moment scheme of finite elements. Under the pre-stresses we mean those stresses that arose in the structure in the initial state, i.e. before the deformation process under consideration, before the application of the working load.

The solvating relations in general case can be represented as:

$$
\left[K^{s t}+K_{0}^{s t}\right]\left\{u_{t}\right\}=\left\{P^{s}\right\}
$$

where $K_{0}^{s t}$ - incremental geometric matrix of stiffness, which taking into account the action of prestresses [13].

When forming a matrix $K^{\text {st }}$ for a weakly compressible elastomeric layer, a moment scheme of finite elements with triple approximation of displacement fields, deformations, and volume change functions is used. [14].

The components of the stress tensor are determined by the Duhamel Neumann thermoelasticity law. To solve the problem of calculating the temperature of dissipative heating, it is necessary to solve the problem of thermal conductivity. To construct a thermal conductivity matrix for a layered finite element, the hypothesis of continuity of temperature fields and heat fluxes at the interface is used.

In matrix form, the system of equations for the layer takes the form:

$$
[H]\{T\}+\left[H^{(s t)}\right]\{T\}+\{P\}+\{S\}=0,
$$

where $H$ - thermal conductivity matrix, $H^{(s t)}$ - matrix conditioned to boundary conditions of the $3 \mathrm{rd}$ kind on the surface of the construction, $P$ - equivalent load vector conditioned to the internal heat generation source, $S$ - equivalent load vector conditioned to heat fluxes and body surface temperature.

The heat generation function is calculated as averaged over the deformation cycle.

The solution of the linked problem is performed using the method of successive approximations.

2. Results of the calculation and analysis of solutions. Let us consider the process of determining the temperature of dissipative heating of elastomeric structures as a solution of the linked problem of thermoelasticity for a stable 
mode of cyclic deformation and heat exchange with the environment. In this case, the solution of the quasi-static thermoelasticity problem requires the solution of several problems: determination of the function of internal sources in an elastic - hereditary body (solution of the thermoelasticity problem) at the initial temperature; calculation of the temperature field under given boundary conditions (solving the problem of stationary thermal conductivity); solving the problem of thermoelasticity for the final temperature of self-heating. When constructing a mathematical model of the problem, it is assumed that the stress state significantly depends on the coordinates, as a result of which the field of heat and temperature sources is inhomogeneous. In addition, there is a need to take into account the dependence of physical and mechanical properties on temperature. The method of successive approximations is used to solve the related thermoelasticity problem.

The algorithm for solving the related problem is represented by the following sequence:

1. From the solution of the thermoelasticity problem $\left[K^{i j}\right]\left\{u_{j}\right\}=\left\{P^{i}\right\}$ the vector of nodal displacements $\left\{u_{i}\right\}$ at the set amplitude of fluctuations is defined. Vector of the right part $\left\{P^{j}\right\}$ determined by the stiffness matrix taking into account the initial stresses and boundary conditions in the form of displacements on the surface of the finite element. For a separated finite element the vector of internal forces is determined by the formula:

$$
\left\{P^{s}\right\}=[A]^{T}\left[F_{i j}^{s}\right]^{T}\left[E^{i j k l}\right]\left[F_{k l}^{t}\right][A]\left\{u_{t}\right\}+[A]^{T}\left[F_{(\theta)}^{s}\right]^{T}\left[E^{(\theta)}\right]\left[F_{(\theta)}^{t}\right][A]\left\{u_{t}\right\}
$$

where the first term is a vector due to elastic displacements, the second term is a

vector of forces due to thermal displacements.

2. To determine the power of internal heat generation sources, it is necessary to determine the amount of scattered energy per load cycle.

The use of the simplest hypotheses about the homogeneity of the displacement field in the direction of reinforcement and the homogeneity of the field of generalized forces for shear stresses and normal stresses to the fibers, allows you to calculate the power of internal heat sources as an average, equal to dissipative energy. The power of internal sources for cyclic loading can also be determined by the formula:

$$
w_{0}^{(k)}=\frac{\omega}{2 \pi} \int_{0}^{2 \pi / \omega} \sigma_{(k)}^{i j} \dot{\varepsilon}_{i j}^{(k)} d t .
$$

3. The temperature field is determined from the solution of the stationary thermal conductivity problem.

The thermal conductivity problem is nonlinear because the matrix $[H]$ and the equivalent heat load vector $\{R\}$ depends on temperature.

The system of solving equations of stationary thermal conductivity using the method of successive approximations is written in the form: 


$$
\left[H_{(k-1)}\right]\left\{T_{(k)}\right\}=-\left\{R_{(k-1)}\right\} .
$$

The iterative process of solving problem continues until the specified calculation accuracy is reached.

After determining the temperature procedure begins with the 1st point. In case when physical and mechanical properties of the material depend on temperature, at each iteration components of the tensor of elastic characteristics, components of the tensor of thermal conductivity, as well as the component of the matrices of rigidity and thermal conductivity of the construction are recalculated.

3. Results of the calculation and analysis of solutions. To study the convergence of the results obtained using the proposed approach, we consider solutions of problems for which the literature provides solutions based on other approaches.

Problem 1. Consider the deformation of a layered thermosensitive cylindrical shell, the left end of which is rigidly clamped, and the right free, which is under the influence of a non-uniform stationary temperature field of the form [15]:

$$
T^{(k)}=T_{0}^{(k)}(z)+T_{1}^{(k)}(z), k=1,2, \ldots, n,
$$

where $n$-number of layers; $z$ - the coordinate calculated along the outer normal to the middle surface of the cylinder.

Physical and-mechanical characteristics of the layers depends on temperature:

$$
\begin{gathered}
E_{i}^{(k)}=E_{i 0}^{(k)}\left(1+\xi_{i}^{(k)} T^{(k)}\right), G^{(k)}=G_{0}^{(k)(k)}\left(1+\eta^{(k)} T^{(k)}\right), \\
\alpha_{i}^{(k)}=\alpha_{i 0}^{(k)}\left(1+\gamma_{1 i}^{(k)} T^{(k)}+\gamma_{2 i}^{(k)} T^{(k) 2}\right), \quad i=1,2,3,
\end{gathered}
$$

where $\xi_{i}^{(k)}, \eta^{(k)}, \gamma_{1 i}^{(k)}, \gamma_{2 i}^{(k)}$ - experimentally determined constants, which characterize the dependence of elastic modules and coefficients of thermal expansion on temperature.

The Poisson's ratio for the thermosensitive materials, which are under consideration, is almost independent of temperature, so we consider it constant. The components of the stress tensor arising from the temperature are determined by the Duhamel-Neumann law.

Physical and mechanical parameters are taken as follows:

$$
\begin{aligned}
& E_{10}=E_{30}=1,704 \cdot 10^{10} \mathrm{~Pa} ; \quad E_{20}=2,808 \cdot 10^{10} \mathrm{~Pa} ; \quad \mu_{0}=\frac{E_{10}}{50} ; \quad \eta=\xi_{1} ; \\
& v_{12}=0,106 ; \quad v_{21}=v_{13}=0,174 ; \quad v_{23}=0,064 ; \quad \xi_{1}=\xi_{2}=\xi_{3}=-0,25 \cdot 10^{-2} ; \\
& \gamma_{2 i}=0(i=1,2,3) ; \quad \gamma_{11}=-0,2413 \cdot 10^{-7} \mathrm{~K}^{-1} ; \quad \gamma_{13}=0 ; \gamma_{12}=-0,2445 \cdot 10^{-7} \mathrm{~K}^{-1} ; \\
& \alpha_{10}=0,1134 \cdot 10^{-4} \mathrm{~K}^{-1} ; \alpha_{20}=0,1418 \cdot 10^{-4} \mathrm{~K}^{-1} ; \alpha_{30}=0 ; \quad l=0,2 \mathrm{~m} ; 2 h=0,04 \mathrm{~m} ; \\
& R=0,4 \mathrm{~m} .
\end{aligned}
$$


The constructed system of equations in displacements with variable coefficients is solved using the proposed approach. The obtained results satisfactorily coincide with the results obtained in analytical and approximate solutions using shell theory by the authors [15].

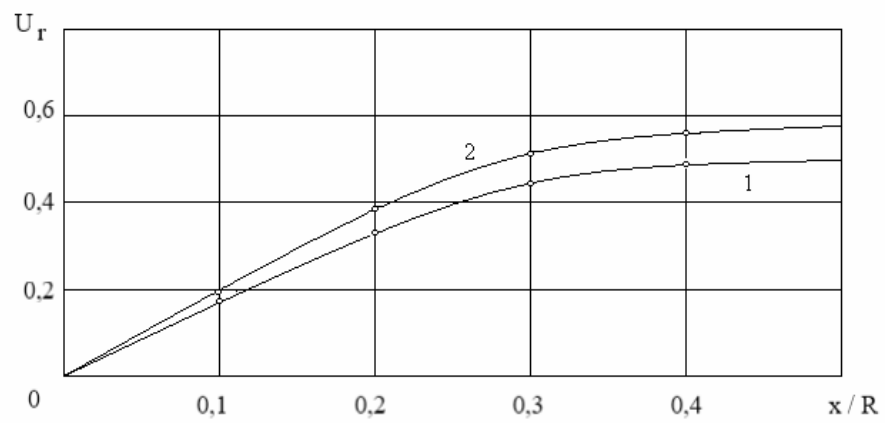

Fig. 2. Distribution of radial displacements

Fig. 2 shows graphs of radial displacements, obtained using the MIRELA+ complex (curve 1) and the authors [15].

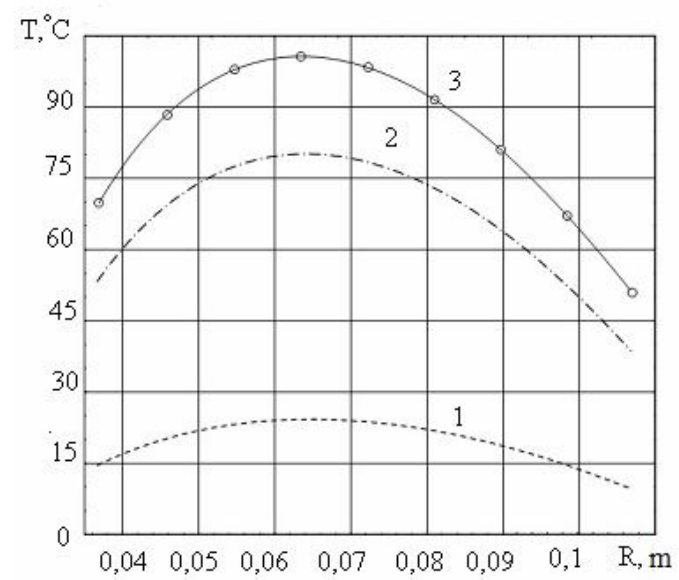

Fig. 3. Temperature distribution in the cross-section $z=h / 2$

Preliminary deformation: 1) $\Delta=0$; 2) $\Delta=0,01 \mathrm{~m}$; 3) $\Delta=0,02 \mathrm{~m}$

Problem 2. Dissipative heating of a hollow cylindrical shock absorber under preload conditions. The sizes of the shock-absorber: $R_{1}=0,035 \mathrm{~m}, R_{2}=0,1 \mathrm{~m}$, $h=0,175 \mathrm{~m}$. Elastic characteristics of rubber 2959: equilibrium shear modulus $\mu=0,74 \mathrm{MPa}$, instantaneous shift module $\mu_{0}=1,76 \mathrm{MPa}, \quad v=0,499$; rheological parameters of Rabotnov's relaxation nucleus $\alpha=-0,6 ; \beta=1,062$; $\chi=0,64$. Amplitude of axial oscillations $\delta=0,008 \mathrm{~m}$, frequency $\omega=40 \mathrm{~s}^{-1}$. 
Thermal conductivity coefficient $\lambda=0,293 \mathrm{~W} /(\mathrm{m} \cdot \mathrm{K})$; the heat transfer coefficients with the metal fittings and the environment are respectively equals $H_{1}=5240 \mathrm{~m}^{-1}, H_{2}=40 \mathrm{~m}^{-1}$.

In fig. 3 shows graphs of the distribution of the steady-state temperature of self-heating with preliminary deformation $(2,3)$ and without pre-compression. Analysis of the results shows that the increase in the initial deformation significantly affects the temperature of dissipative heating.

Conclusions. An algorithm for solving the related problems of thermoelasticity of elastomeric elements is built on the basis of the moment scheme of finite elements. Incremental theory is used to model the processes of deformation of structures with initial stresses.

The analysis of the obtained results shows that the proposed approach allows to obtain satisfactory calculation results.

Considering the action of prestresses, as well as the dependence of the physical and mechanical properties of the material makes significant adjustments to the values of the calculated values.

\section{REFERENCES}

1. Illiushyn A. A. Fundamentals of the mathematical theory of thermoviscoelasticity / A. A. Illiushyn, B. E. Pobedria. - M.: Nauka, 1970. - 280p.

2. Pobedria B. E. Linked problems of thermoelasticity / B. E. Pobedria // Mechanics of Polymers. -1969.- №3. - P. 415 - 421.

3. Kovalenko A. D. Fundamentals of thermoelasticity / A. D. Kovalenko. - K.: Naukova dumka, 1970. -307 p.

4. Karnaukhov V.H. Linked problems of thermoelasticity theory of plates and shells / V. H. Karnaukhov, Y. F. Kyrychok. - K.: Naukova dumka, 1986. - 221 p.

5. Karnaukhov V. H. Linked problems of thermoviscoelaticity / V. H. Karnaukhov. - K.: Naukova dumka, 1982. $-280 \mathrm{p}$.

6. Zhuk Ya. A. Linked thermomechanical behavior of a three-layer viscoplastic beam under harmonic loading / Ya. A. Zhuk, Y. K. Senchenkov// Applied mechanics.- 2001.- T.37, №1. - P. 93-99.

7. Rabotnov Yu. N. Elements of hereditary mechanics of solids / Yu. N. Rabotnov. - M.: Nauka, 1977.- $384 \mathrm{p}$.

8. Kyrychevskyi $V$. $V$. Nonlinear problems of thermomechanics of constructions from weakly compressible elastomers / V. V. Kyrychevskyi, A. S. Sakharov. - Kyev: Budivelnyk, 1992. -216 p.

9. The finite element method in the design of transport structures / A. C. Horodetskyi, V. Y. Zavorotskyi, A. Y. Lantukh-Liashchenko, A. O. Rasskazov. - M.: Transport, 1981. -143 p.

10. Finite Element Method: Theory, Algorithms, Implementation / V. A. Tolok, V. V. Kyrychevskyi, S. Y. Homeniuk, S. N. Hrebeniuk, D. P. Buvailo. - K.: Naukova dumka, 2003. - 316 p.

11. Novatskyi V. Dynamic problems of thermoelasticity / V. Novatskyi.-M.: Myr, 1975.-256 p.

12. Vashizu K. Variational methods in elasticity and plasticity / K. Vashizu.- M.: Myr, 1987. - 542 p.

13. Dokhniak B. M. Calculation of prestressed elastomer constructions / B. M. Dokhniak, Yu. H. Kozub // Proc. 13 Int. Symposium "Problems of tire and rubber-cord composites". - M: SRC NIISP. - October 14-18, 2002. - P. 119-123.

14. The finite element method in the computing complex "MIRELA+" / V.V.Kyrychevskyi, B. M. Dokhniak, Yu. H. Kozub, S. I. Homeniuk, R. V. Kyrychevskyi, S. N. Hrebeniuk.- K.: Naukova dumka, 2005. - 402p.

15. Khoroshun L. P. Determination of the axisymmetric stress-strain state of thermosensitive shells of revolution by the method of spline collocation / L. P. Khoroshun, S. V. Kozlov, I. Yu. Patlashenko // Applied mechanics. - 1988.- T.24, №6.-P. 56 - 63. 
Баженов В.А., Козуб Ю.Г., Солодей I.І.

\section{ТЕРМОПРУЖНІСТЬ ЕЛАСТОМЕРНИХ КОНСТРУКЦИЙ 3 ПОЧАТКОВИМИ НАПРУЖЕННМИ}

У статті представлено алгоритм вирішення зв'язаних задач термопружності еластомерних елементів конструкцій на основі моментної схеми скінченних елементів. Для моделювання процесів термопружного деформування конструкцій 3 початковими напруженнями використовується інкрементальна теорія деформованого твердого тіла. На кожному кроці деформування виконується коригування матриці жорсткості за допомогою інкрементальної геометричної матриці жорсткості. Використання потрійної апроксимації переміщень, деформацій та функції змінення об'єму дозволяє врахувати слабку стисливість еластомерів. Компоненти тензора напружень обраховуються за законом Дюамеля-Неймана. Для розв'язання задачі теплопровідності побудовано матрицю теплопровідності $з$ урахуванням граничних умов на поверхні скінченного елемента. Для розв'язання задачі термопружності використано алгоритм послідовних наближень. На кожному етапі розв'язку обраховуються характеристики термонапруженого стану. На основі отриманих компонентів тензорів напружень та деформацій обраховується інтенсивність джерел внутрішнього теплоутворення як осереднена за цикл навантаження розсіяна енергія. Для обчислення дисипативних характеристик в'язкопружного еластомера використовуються параметри ядра релаксації Работнова. Розв'язання задачі теплопровідності з урахуванням функції внутрішніх джерел тепла дозволяє уточнити температуру нагрівання тіла. На кожному циклі алгоритму проводиться уточнення значень фізико-механічних характеристик термочутливого матеріалу. Наведений підхід до розв'язання задач термопружності реалізовано в обчислювальному комплексі «МІРЕЛА+». На основі розглянутого підходу отримані розв'язки низки задач. Отримані результати задовільно збігаються з розв'язками інших авторів. Врахування дії попереднього навантаження та залежності фізико-механічних властивостей матеріалу від температури приводить до суттєвих коректив розрахункових величин.

Ключові слова: метод скінченних елементів, еластомер, термопружність, дисипативний розігрів, початкові напруження.

\section{УДК 539.3}

Баженов В.А., Козуб Ю.Г., Солодей I.I. Термопружність еластомерних конструкцій 3 початковими напруженнми // Опір матеріалів і теорія споруд: наук.-тех. збірник. К.:КНУБА, 2020. - Вип. 104. - С. 299-308.

Розглянуто метод розв'язання задач термопружності еластомерних конструкиій 3 початковими напруженнями.

Іл. 3. Бібліогр. 15 назв.

\section{UDC 539.3}

Bazhenov V.A., Kozub Yu.G., Solodei I.I. Thermoelasticity of elastomeric constructions with initial stresses // Strength of Materials and Theory of Structures: Scientific-and-technical collected articles - Kyiv: KNUBA, 2020. - Issue 104. - P. 299-308.

A method for solving the problems of thermoelasticity of elastomeric structures with initial stresses is considered.

Il. 3. Ref. 15.

\section{УДК 539.3}

Баженов В.А., Козуб Ю.Г., Солодей И.И. Термоупругость эластомерных конструкций с начальными напряжениями // Сопротивление материалов и теория сооружений. - 2020. Вып. 104. - С. 299-308.

Рассмотрен метод решения задач термоупругости эластомерных конструкиий $c$ начальными напряженями.

Ил. 3. Библиогр. 15 назв. 
Автор (вчена ступень, вчене звання, посада): доктор технічних наук, професор, академік Національної академії педагогічних наук України, директор НДІ будівельної механіки БАЖЕНОВ Віктор Андрійович

Адреса робоча: 03680 Украйна, м. Київ, Повітрофлотський проспект 31, Киёвський національний університет будівництва і архітектури.

Робочий тел.: +38(044) 245-48-29

Мобільний тел.: +38(067)111-22-33

Email: bazhenov.va@knuba.edu.ua

ORCID ID: https//orcid/org/0000-0002-5802-9848

Автор (вчена ступень, вчене звання, посада): доктор технічних наук, доцент, завідувач кафедри фізико-технічних систем та інформатики дз "ЛНУ імені Тараса Шевченка" КОЗУБ Юрій Гордійович

Адреса робоча: 92703 Украӥна, Луганська обл., м. Старобільськ, плоша Гоголя, 1. ДЗ "Луганський національний університет імені Тараса Шевченка"

Робочий тел.: +38(073) 41-303-23

Мобільний тел.: +38(050) 602-56-25

Email: kosub,yg@gmail.com

ORCID ID: https//orcid.org/0000-0002-3366-6031

Автор (вчена ступень, вчене звання, посада): доктор технічних наук, стариий науковий співробітник, заступник директора НДІ будівельної механіки СОЛОДЕЙ Іван Іванович

Адреса робоча: 03680 Украӥна, м. Київ, Повітрофлотський проспект 31, Київський національний університет будівництва і архітектури.

Робочий тел.: +38(044) 241-55-55

Мобільний тел.: +38(050) 357-44-90

Email: solodei.ii@knuba.edu.ua

ORCID ID: https//orcid.org/0000-0001-7638-3085 